\title{
A TOLERANCIA COMO CATEGORÍA IDEOLÓXICA
}

Slavoj Žižek

Universidade de Liubliana 



\section{A CULTURALIZACIÓN DA POLÍTICA}

Por que hoxe en día hai tantos conflitos que se perciben como problemas de intolerancia e non como problemas de desigualdade, explotación ou inxustiza? Por que o remedio que se propón é a tolerancia e non a emancipación, a loita política ou mesmo a loita armada? A resposta inmediata áchase na operación ideolóxica básica do multiculturalista liberal: a "culturalización da política», pola cal as diferenzas políticas -condicionadas pola desigualdade política ou a explotación económica- se naturalizan e se neutralizan ata devir en diferenzas «culturais»; é dicir, diferentes «modos de vida» que constitúen algo dado, algo que non se pode superar; o único que se pode facer é «toleralo». Esta situación esixe unha resposta nas liñas que presenta Walter Benjamin, en Desde a culturalización da política á politización da cultura. A causa desta culturalización é a retirada, o fracaso das solucións políticas directas como o Estado do benestar ou diversos proxectos socialistas. A tolerancia é o seu Ersatz pospolítico ${ }^{1}$.

Foi Samuel Huntington quen propuxo a fórmula desta «culturalización da política» que máis éxito acadou, ao situar a fonte principal dos conflitos de hoxe no "choque de civilizacións», que un está tentado a chamar a doenza de Huntington dos nosos días. Como o expresou Huntington, logo da fin da guerra fría o "pano de aceiro da ideoloxía» fora substituído polo "pano de veludo da cultura ${ }^{2}$. A negra visión que tiña Huntington do «choque de civilizacións» pode parecer todo o contrario das prometedoras perspectivas da fin da Historia de Francis Fukuyama, imaxinadas baixo o aspecto dunha democracia liberal de escala mundial. Que pode ser máis diferente que esa idea pseudohegeliana da «fin da Historia» de Fukuyama -a fórmula suprema da mellor orde social posible

\footnotetext{
${ }^{1}$ Neste punto baséome en boa medida en Brown: Regulating Aversion: Tolerance in the Age of Identity and Empire.

${ }^{2}$ Véxase Samuel Huntington: The Clash of Civilizations, Nova York, Simon and Schuster, 1998.
} 
áchase na democracia liberal capitalista, co cal agora xa non hai cabida para facer máis avances conceptuais; só existen obstáculos empíricos que superar ${ }^{3}-$ que o «choque de civilizacións» de Huntington como a principal loita política do século XXI? O «choque de civilizacións» é a política da fin da Historia.

A oposición básica en que se fundamenta toda a visión liberal é a que existe entre aqueles que están gobernados pola cultura, totalmente determinados pola vida-mundo en que nacen, e aqueles que simplemente «gozan» da súa cultura, que se elevan por riba dela e son libres de escollérena. Isto lévanos ao seguinte paradoxo: a fonte última da barbarie é a cultura mesma, é o feito de identificarse un directamente cunha cultura particular o que o fai intolerante con outras culturas. Neste punto, a oposición básica establécese entre o colectivo e o individual: a cultura é, por definición, colectiva e particular, provinciana, exclúe outras culturas, mentres que -seguinte paradoxo- é o individuo o que é universal, o lugar onde radica a universalidade, na medida en que ese individuo se libera da súa cultura concreta e se eleva por riba dela. No entanto, como todo individuo ten que particularizarse dalgún xeito, ten que morar nunha vida-mundo concreta, o único modo de saír deste punto morto consiste en dividir o individuo en universal e particular, público e privado -abranguendo "privado» tanto o refuxio da familia como a esfera pública non estatal da sociedade civil: a economía. No liberalismo, a cultura sobrevive, mais privatizada: como modo de vida, como conxunto de crenzas e prácticas, non como rede pública de regras e normas. A cultura, xa que logo, experimenta unha transubstanciación: os mesmos conxuntos de crenzas e prácticas mudan e pasan de ser o poder vinculante do colectivo a constituír unha expresión de idiosincrasias persoais e privadas. $\mathrm{Na}$ medida en que a propia cultura é a fonte da barbarie e da intolerancia, a conclusión inevitable é que o único xeito de superar a intolerancia e a violencia consiste en liberar o núcleo do ser do suxeito, a súa esencia universal, da cultura: no seu núcleo, o suxeito ten que ser kulturlos ${ }^{4}$. O piar filosófico desta ideoloxía do suxeito liberal universal é o suxeito cartesiano, en especial na súa versión kantiana. Este suxeito enténdese como un ser capaz de saír das súas raíces culturais

\footnotetext{
${ }^{3}$ Francis Fukuyama: The End of History and the Last Man, Nova York, Free Press, 2006, (reimpresión).

${ }^{4}$ Con isto, por certo, dá un novo xiro a infame fórmula de Joseph Goebbels «Cando oio a palabra "cultura”, bótolle man á pistola..., mais non, por suposto, cando oio a palabra "civilización”».
} 
e sociais concretas e de afirmar a súa total autonomía e universalidade; de feito, a experiencia en que se cimenta a postura de Descartes da dúbida universal é precisamente a experiencia «multicultural» de que a tradición dun non é mellor que o que para nós son as «excéntricas» tradicións dos demais:

A min ensináranme, mesmo na miña época universitaria, que non hai nada imaxinable que sexa tan estraño ou tan pouco crible que non o teña mantido xa algún filósofo, e eu, por outra banda, recoñecín no transcurso das miñas viaxes que aqueles cuxos sentimentos difiren moito dos nosos non son necesariamente, con todo, bárbaros ou salvaxes, senón que poden estar en posesión da razón na mesma medida que nós ou mesmo máis 5 .

Por este motivo, para un filósofo cartesiano, as raíces étnicas, a identidade nacional, etc. simplemente non son unha categoría de verdade, ou, para dicilo cos precisos termos kantianos, cando reflexionamos sobre as nosas raíces étnicas facemos un uso privado da razón, limitado por presuposicións dogmáticas continxentes; é dicir, actuamos como individuos «inmaturos», non como seres humanos libres que moran na dimensión da universalidade da razón. Rara vez se menciona a oposición existente entre Kant e Rorty no tocante a esta distinción do público e do privado, mais non por iso deixa de ser fundamental: ambos distinguen claramente entre eses dous dominios, mais de xeitos opostos. Así, para Rorty, o gran liberal contemporáneo de todos os tempos, o privado é o espazo da nosa idiosincrasia, onde rexen a creatividade e a imaxinación desbocada e as consideracións morais están «case» suspendidas, mentres que o público é o espazo da interacción social, onde debemos obedecer as regras para non lles facermos mal aos demais; noutras palabras, o privado é o espazo da ironía, mentres que o público é o espazo da solidariedade. No entanto, para Kant o espazo público da «sociedade civil mundial» designa o paradoxo da singularidade universal, dun suxeito singular que, grazas a unha especie de curtocircuíto, evitando a mediación do particular, participa directamente no Universal. Isto é o que quere dicir Kant na famosa pasaxe do seu Que é a Ilustración?, cando fala do "público» en oposición ao "privado»: «privado» non se refire aos vínculos

\footnotetext{
${ }^{5}$ René Descartes: Discourse on Method, South Bend, University of Notre Dame Press, 1994, p. 33.
} 
individuais, en contraposición aos comunitarios, senón á propia orde comunitario-institucional daquilo con que un se identifica en particular; o "público», pola súa banda, é a universalidade transnacional do exercicio da nosa razón. $\mathrm{O}$ paradoxo da fórmula subxacente «pensa libremente, mais obedece!», que, abofé, presenta unha serie de problemas en si, xa que tamén se basea na distinción entre o nivel "performativo» da autoridade social e o nivel de pensamento libre onde queda suspendida a performatividade, consiste en que un participa na dimensión universal da esfera "pública» precisamente como individuo singular extraído da súa identificación comunitaria substancial, ou mesmo oposto a ela; que non é verdadeiramente universal agás cando é radicalmente singular, nos intersticios das identidades comunitarias. A este respecto, é Kant quen debería entenderse como o crítico de Rorty; na súa visión do espazo público do exercicio libre e sen limitacións da razón, afirma a dimensión da universalidade emancipadora fóra dos confíns da nosa identidade social, da nosa posición dentro da orde do ser social: a dimensión que falta en Rorty.

\section{A UNIVERSALIDADE EFECTIVA}

É doado problematizar esta noción liberal de tolerancia e facer palpable a violencia que a sostén. En primeiro lugar, non é verdadeiramente universal, kulturlos, carente de cultura. Dado que nas nosas sociedades segue a predominar unha división sexualizada do traballo que lles confire un xiro masculino a categorías liberais básicas -autonomía, actividade pública, competencia- e relega as mulleres á esfera privada da solidariedade familiar, o propio liberalismo, coa súa oposición entre o privado e o público, sérvelle de acubillo ao dominio masculino. É máis, só para a cultura capitalista occidental moderna a autonomía e a liberdade individual ocupan un lugar superior á solidariedade colectiva, a conexión, a responsabilidade para cos dependentes, o deber de respectar os costumes da comunidade á que un pertence. O propio liberalismo, xa que logo, dálle prioridade a unha determinada cultura: a cultura occidental moderna. Canto á liberdade de elección, o liberalismo tamén está caracterizado por un forte prexuízo: é intolerante cando non se lles dá liberdade de elección aos individuos doutras culturas -como é evidente en cuestións como a ablación de clítoris, os 
matrimonios de menores, o infanticidio, a poligamia e a violación no ámbito familiar. No entanto, o liberalismo pasa por alto a tremenda presión que, por exemplo, obriga ás mulleres da nosa sociedade liberal a sometérense a procedementos como a cirurxía plástica, os implantes estéticos e as inxeccións de Botox para seguiren a ser competitivas no mercado do sexo.

A idea liberal da «libre escolla» sempre acaba atrapada nun punto morto. $\mathrm{O}$ suxeito pode optar pola tradición provinciana en que naceu, pero primeiro hai que presentarlle alternativas para el despois ser quen de escoller libremente. Os adolescentes amish, pola súa parte, formalmente teñen liberdade de elección, mais as condicións en que se atopan á hora de faceren a escolla determinan que esta non sexa libre. Para gozaren de auténtica liber dade de elección, terían que ser informados axeitadamente de todas as opcións e recibir unha educación sobre elas; mais o único modo de facer isto sería sacalos do seu arraigamento na comunidade amish e que se americanizasen. Neste punto tamén se ven as limitacións que padece a actitude liberal oficial con respecto ás musulmás que levan veo. Estas mulleres teñen permiso para leváreno se é por libre escolla e non se trata dunha opción imposta polo seu home ou pola familia; porén, no momento en que unha muller pon o veo para exercer unha escolla individual libre, por exemplo para levar á práctica a súa propia espiritualidade, o significado do veo muda por completo. Xa non é un signo da súa pertenza á comunidade musulmá, senón unha expresión da súa individualidade idiosincrásica. A diferenza é a mesma que a que hai entre un campesiño chinés que come comida chinesa porque na súa vila iso se fai desde tempos inmemoriais, e un cidadán dunha megalópole occidental que decide ir cear a un restaurante chinés por onde vive. Este é o motivo polo cal, nas nosas sociedades seculares baseadas en escollas, as persoas que manteñen unha pertenza relixiosa fundamental se atopan nunha posición subordinada: mesmo se se lles permite mantela, esta crenza "tolérase» por ser a súa escolla ou opinión persoal idiosincrásica, mais no momento en que a presentan publicamente como o que é para eles -por exemplo, unha cuestión de pertenza fundamental- son acusados de «fundamentalismo». $\mathrm{O}$ que isto quere dicir é que o «suxeito da libre escolla», no sentido multicultural e "tolerante» occidental, só pode xurdir como consecuencia dun proceso extremadamente violento polo cal é arrincado dunha vida-mundo particular, cortado das súas raíces. 
Sempre deberiamos ter en conta o aspecto tremendamente liberador desta violencia grazas á cal experimentamos a continxencia da nosa orixe cultural. Non esquezamos que o liberalismo apareceu en Europa logo da catástrofe da Guerra dos Trinta Anos entre católicos e protestantes, que lle deu resposta a unha urxente pregunta: como poden coexistir persoas que difiren na súa filiación relixiosa? O liberalismo reclamáballes aos cidadáns máis ca unha tolerancia condescendente polas relixións diferentes, máis ca a tolerancia como amaño temporal. Reclamaba que respectásemos outras relixións non malia as nosas conviccións relixiosas máis fondas, senón debido a elas, pois respectar os demais é unha proba de que se teñen verdadeiras crenzas. Esta actitude expresouna co maior acerto Abu Hanifa, o grande intelectual musulmán do século VIII: «A diversidade de opinións na comunidade é unha proba da misericordia Divina» ${ }^{6}$. Só no marco deste espazo ideolóxico pode un experimentar a propia identidade como algo continxente e "construído" de xeito discursivo. En suma, filosoficamente non existe Judith Butler ningunha, nin a súa teoría da enunciación performativa da identidade de xénero, sen o suxeito cartesiano. Independentemente de todas as cousas de que poidamos acusar o multiculturalismo liberal, deberiamos admitir polo menos que é profundamente "antiesencialista»: é o seu bárbaro Outro o que se percibe como existencialista e, polo tanto, falso, pois o fundamentalismo "naturaliza» ou «esencializa» trazos continxentes condicionados historicamente. Para os europeos modernos, as demais civilizacións están atrapadas na súa cultura particular, mentres que eses europeos modernos son flexibles e cambian de presupostos continuamente.

Os críticos "poscoloniais» gustan de subliñar o insensible que é o liberalismo coa súa propia limitación: á hora de defender os dereitos humanos, tende a impoñerlles a outros a súa versión deses dereitos. Porén, a sensibilidade autorreflexiva ante as propias limitacións só pode xurdir contra o pano de fondo das nocións de autonomía e racionalidade promovidas polo liberalismo. Pódese argüír, xaora, que, en certo modo, a situación de Occidente é aínda peor porque nel se esvaece a opresión, se enmascara como libre escolla - «E logo de que te queixas? Fuches ti quen decidiu facelo...». A nosa liberdade de elección, efecti-

${ }^{6}$ Cita de Ziauddin Sardar e Merryl Wyn Davies: The No-Nonsense Guide to Islam, Londres, New Internationalist and Verso Books, 2004, p. 77. 
vamente, adoita funcionar como mero xesto formal de consentimento da opresión e a explotación ás que un se ve sometido. Non obstante, neste punto é importante lembrar a lección de Hegel: a forma posúe unha autonomía e unha eficacia propias, de xeito que, cando comparamos unha muller do Terceiro Mundo que se ve na obriga de someterse a unha ablación de clítoris ou que foi prometida en matrimonio cando era unha meniña, cunha muller do Primeiro Mundo que é «libre de escoller» unha dolorosa cirurxía estética, importa a forma da liberdade, pois abre un espazo para a reflexión crítica.

O que é máis: a cara oposta do rexeitamento doutras culturas por intolerantes, bárbaras, etc., é a admisión, demasiado doada, da súa superioridade. Non constitúe un dos topoi do liberalismo occidental enxalzar o outro por levar unha vida máis harmoniosa, orgánica, menos competitiva e encamiñada á cooperación, non ao dominio? Vinculada a esta operación hai outra: pechar os ollos á opresión no nome do «respecto» pola cultura do outro. Por poñer o caso máis evidente, o dominio colonial británico na India non constitúe unicamente a historia dun arrogante proceso de civilización, senón tamén a historia dun pacto feito coa vella clase dirixente india, á que se lle permitiu continuar coa súa explotación e a súa opresión dado que este era o seu antigo «modo de vida». Neste punto, mesmo se apela á liberdade de elección, deformándoa: esas persoas escolleron o seu modo de vida, que inclúe queimar as viúvas, e por deplorable e repulsivo que nos pareza debemos respectar a súa escolla.

Así, a crítica poscolonial «radical» do liberalismo segue no habitual nivel marxista de denunciar a falsa universalidade, de amosar como unha postura que se presenta como neutral-universal privilexia, de feito, unha cultura determinada -heterosexual, masculina, cristiá. Máis precisamente, segue ancorada na postura antiesencialista posmoderna oficial, unha especie de versión política da noción foucaultiana do sexo en canto que xerado pola multitude de prácticas da sexualidade: neste punto o "home», o suxeito dos Dereitos Humanos, xérase mediante un conxunto de prácticas políticas que materializan a cidadanía. Os dereitos humanos xorden como falsa universalidade ideolóxica que enmascara e lexitima a política concreta do imperialismo e o dominio, as intervencións militares e o neocolonialismo occidentais. Abonda isto para constituír unha crítica?

A interpretación sintomática marxista pode demostrar, de xeito convincente, o particular contido que lle dá a interpretación ideolóxica burguesa, en concre- 
to, á noción de dereitos humanos: os dereitos humanos universais son, efectivamente, os dereitos que teñen os propietarios homes e brancos a faceren libres intercambios mercantís e a explotaren os traballadores e as mulleres, así como a exerceren o dominio político. Porén, identificar ese contido específico que logra facerse coa hexemonía da forma universal só é a metade da historia; a outra metade, fundamental, consiste en formular unha pregunta complementaria moito máis difícil: a do xurdimento da forma mesma de universalidade. Como e en que condicións históricas concretas a propia universalidade abstracta se torna unha «realidade da vida social»? En que condicións os individuos teñen conciencia de si mesmos en canto que suxeitos de dereitos humanos universais? Velaquí o núcleo da análise marxista do fetichismo da produción: nunha sociedade en que predomina o intercambio de produtos, os propios individuos, na súa vida diaria, relaciónanse con eles mesmos e cos obxectos con que se atopan en canto que encarnacións continxentes de nocións abstractas e universais. $\mathrm{O}$ que eu son, a miña orixe social ou cultural particular, experiméntase como continxente, xa que o que en última instancia me define é a capacidade abstracta universal de pensar ou traballar, ou ambas as dúas. Todo obxecto que poida satisfacer o meu desexo experiméntase como continxente, xa que o meu desexo se concibe como unha capacidade formal abstracta, indiferente ante a multitude de obxectos concretos que poden satisfacelo, pero que nunca o logran de todo. A noción moderna de profesión implica que eu me experimento a min mesmo como individuo que non «nace» directamente nese rol social, senón que o que eu vou ser depende da interacción entre as circunstancias socias continxentes e a miña liberdade de escolla. Nese respecto, o individuo contemporáneo ten unha profesión -é electricista, profesor ou camareiro-, mais non ten sentido afirmar que un servo medieval era campesiño de profesión. Sobre esta cuestión, o fundamental, outra vez, é que, en determinadas condicións sociais de intercambio de mercadorías e de economía mundial de mercado, a «abstracción» se torna unha característica directa da vida social actual, inflúe no modo de comportárense individuos particulares e garda relación co seu destino e a súa contorna social. Marx comparte a apreciación de Hegel de que a universalidade se transforma "para si mesma» só na medida en que os individuos xa non identifican de todo o celme do seu ser coa súa situación social particular. Unha circunstancia que iso comporta é que eses mesmos individuos teñen a experiencia 
de estaren «dislocados» con respecto a tal situación: a existencia concreta e efectiva da universalidade produce un individuo carente dun lugar axeitado no edificio global. Nunha estrutura social dada, a universalidade transfórmase "para si mesma» só naqueles individuos que carecen dun lugar axeitado nela. Daquela, o modo de aparición dunha universalidade abstracta, o seu nacemento real, produce violencia, pois altera violentamente unha compostura orgánica anterior.

Xa non abonda con alegar a vella cuestión marxista sobre a fenda existente entre a aparencia ideolóxica da forma legal universal e os intereses particulares que efectivamente a sosteñen, como é tan común entre os críticos de esquerdas politicamente correctos. Ten plena validez o contraargumento presentado por teóricos como Claude Lefort ${ }^{7}$ e Jacques Rancière ${ }^{8}$ acerca de que a forma nunca é unha «mera» forma, senón que comporta unha dinámica de seu que deixa pegadas na materialidade da vida social; ao cabo, a «liberdade formal» da burguesía pon en marcha o proceso de reivindicacións e prácticas totalmente «materiais», desde os sindicatos ao feminismo. Con razón Rancière subliña a radical ambigüidade da noción marxista de fenda entre a democracia formal, co seu discurso sobre os dereitos do home e a liberdade política, e a realidade económica da explotación e a dominación. Esta fenda existente entre a «aparencia» de igualdade-liberdade e a realidade social das diferenzas económicas e culturais pódese interpretar no sentido sintomático habitual, é dicir, aseverando que a forma dos dereitos universais, a igualdade, a liberdade e a democracia non é senón unha expresión necesaria, mais ilusoria, do seu contido social concreto, o universo da explotación e a dominación de clase. Pero tamén pode interpretarse no sentido, moito máis subversivo, da existencia dunha tensión na cal a "aparencia» de égaliberté dista moito, precisamente, de ser unha "mera aparencia», posto que en realidade ten un poder de seu que lle permite pór en marcha o proceso de artellar novamente as relacións socioeconómicas reais, "politizándoas» de xeito progresivo: por que non van poder votar tamén as mulleres?, por que non poden ser tamén un asunto de interese político público as condicións laborais?, e outras. Neste punto, un vese tentado de empregar ese antigo termo levistraussiano da "eficacia simbólica»: a aparencia de égaliberté é unha ficción simbólica

\footnotetext{
7 Véxase Claude Lefort: The Political Forms of Modern Society: Bureaucracy, Democracy, Totalitarianism, Cambridge, MIT Press, 1986.

${ }^{8}$ Véxase Jacques Rancière: Hatred of Democracy, Londres, Verso Books, 2007.
} 
que, como tal, posúe eficacia real por si. Hai que resistir a escéptica tentación de reducila a unha mera ilusión que oculta unha realidade diferente, pois iso sería caer na trampa da vella hipocrisía stalinista, que se burlaba da liberdade burguesa «meramente formal»; de feito, se era tan meramente formal e non alteraba as auténticas relacións de poder, daquela por que non a permitiu o réxime de Stalin? Por que lle tiña tanto medo?

O momento clave de toda loita teórica, e abofé que tamén de toda loita ética, política e, como demostrou Badiou, mesmo estética, está no ascenso da universalidade para alén da vida-mundo concreta. Hai que inverter o tópico de que todos estamos ancorados irredutiblemente nunha vida-mundo particular e continxente e, así, toda a universalidade se tingue irredutiblemente desa vida-mundo en que está irredutiblemente inserida. $\mathrm{O}$ auténtico momento de descubrimento, o avance fundamental, acontece cando unha dimensión propiamente universal estoupa no interior dun contexto particular e se transforma "para si», e se experimenta directamente a súa universalidade. Tal «universalidade para si» non é simplemente externa ao seu contexto específico, nin está por riba del: inscríbese nel. Pertúrbao e aféctao desde dentro e, en consecuencia, a identidade do particular divídese entre o seu aspecto particular e o universal. Sen dúbida Marx xa subliñou que, en realidade, o problema que presentaba Homero non era o de explicar que as raíces da súa épica se achaban nos primeiros tempos da sociedade grega, senón o de dar conta de que, malia que claramente arraigada no seu contexto histórico, puido transcender a súa orixe histórica e falarlles a todas as épocas. Talvez a proba hermenéutica máis elemental da grandeza dunha obra de arte é a súa capacidade de supervivencia cando se arrinca do seu contexto orixinal. No caso da arte verdadeiramente magnífica, todas as épocas a reinventan e a redescobren; por iso hai un Shakespeare romántico e un Shakespeare realista.

Nas óperas de Richard Wagner temos outro exemplo. Nos traballos historicistas recentes téntase extraer o "auténtico significado» contextual de diversos personaxes e temas: o pálido Hagen é en realidade un xudeu que se masturba, a ferida de Amfortas en realidade é sífilis, e demais. Segundo esta argumentación, Wagner estaba a mobilizar códigos históricos que no seu tempo eran coñecidos por todos: cando alguén tropeza, canta en tons agudos soltando galos ou fai acenos nerviosos, "todos» sabían daquela que estaban ante un xudeu. Por ese motivo, Mime, de Sigfrido, é a caricatura dun xudeu. A doenza que ten na ingua 
derivada das relacións mantidas cunha muller «impura», era unha obsesión na segunda metade do século XIX por mor da sífilis, de xeito que todo o mundo tiña claro que Amfortas en realidade collera a sífilis de Kundry.

O primeiro problema que presentan estas interpretacións é que, mesmo de seren correctas, as percepcións que se tiran delas non achegan moito para poder entender a obra de xeito relevante. Abofé que os tópicos historicistas poden facer esvaecer o contacto que temos coa arte. Para captar axeitadamente Parsifal, un ha de abstraerse desas trivialidades históricas, decontextualizar a obra, arrincala do contexto en que orixinalmente se insería. Hai máis verdade na estrutura formal de Parsifal, que permite diferentes contextualizacións históricas, que no seu contexto orixinal, e foi Nietzsche, o gran crítico de Wagner, o primeiro en realizar unha decontextualización así ao propoñer unha nova figura de Wagner: xa non Wagner o poeta da mitoloxía teutoa, da grandilocuente grandeza heroica, senón o Wagner «miniaturista», o Wagner da feminidade imbuída de histeria, das pasaxes delicadas, da decadencia familiar burguesa.

No mesmo sentido, o propio Nietzsche foi reinventado unha e outra vez ao longo do século XX: desde o Nietzsche protofascista heroico-conservador pasou a ser o Nietzsche francés e logo o Nietzsche dos estudos culturais. Mediante análises históricas convincentes pódese amosar con facilidade que a teoría de Nietzsche se insería na súa experiencia política particular -así, o que desencadeou a súa «revolta dos escravos» foi a Comuna de París-, mais isto en ningún modo contradí o feito de que hai máis verdade no Nietzsche francés "descontextualizado» de Deleuze e Foucault que neste Nietzsche correcto en sentido histórico. O argumento para afirmalo non é simplemente pragmático. Ha de advertirse que non se trata de que a interpretación que Deleuze fai de Nietzsche, malia que historicamente incorrecta, sexa máis produtiva; trátase, polo contrario, de que a tensión que existe entre o marco básico universal do pensamento de Nietzsche e a contextualización histórica concreta desas ideas se inscribe no edificio mesmo do pensamento nietzscheano, forma parte da súa propia identidade, do mesmo xeito que a tensión existente entre a forma universal dos dereitos humanos e o seu "auténtico significado» no momento histórico da súa concepción forma parte da identidade deses dereitos.

Daquela, a hermenéutica marxista oficial, consistente en desenterrar a específica parcialidade da universalidade abstracta, debería complementarse co seu 
oposto: co procedemento propiamente hegeliano que desvela a universalidade do que se presenta como unha postura concreta. Paga a pena volver considerar a análise de Marx de como, durante a Revolución Francesa de 1848, o republicano-conservador Partido da Orde funcionou como coalición das dúas pólas monárquicas, os orleanistas e os lexitimistas, no "reino anónimo da República»? Os deputados parlamentarios do Partido da Orde percibían o seu republicanismo como burla: nos debates parlamentarios non deixaban de cometer lapsus monárquicos e ridiculizaban a República para que se soubese que o verdadeiro obxectivo do Partido era o de restaurar o Reino. Do que non se decataban era de que eles mesmos estaban enganados con respecto ao impacto social real do seu dominio. $\mathrm{O}$ que en verdade estaban a facer era establecer as mesmas condicións da orde republicana burguesa que tanto desprezaban; por exemplo, ao garantiren que a propiedade privada non estaba en perigo. Así que non se trataba simplemente de que fosen monárquicos con máscara republicana, malia que eles se percibisen como tales: eran as súas propias conviccións monárquicas interiores as que constituían unha fachada enganosa que enmascaraba o seu verdadeiro rol social. En suma, lonxe de ser a verdade oculta do seu republicanismo público, o seu sincero sentimento monárquico era o fantasmático punto de apoio do seu verdadeiro republicanismo. Era a fonte da paixón que puñan na súa actividade.

Non é esta a mesma lección que se pode tirar da «astucia da razón» de Hegel? Abofé, a particularidade pode enmascarar a universalidade. A propósito de Nietzsche, G. K. Chesterton escribiu que «negaba o egoísmo simplemente predicándoo»: «Predicar unha cousa é regalala. Primeiro o egoísta chámalle á vida guerra sen cuartel, e logo pon o máximo coidado posible en instruír os seus inimigos nas cuestións bélicas. Predicar o egoísmo é practicar o altruísmo» ${ }^{10}$. Aquí, o medio non é a mensaxe; todo o contrario, pois o propio medio que empregamos -a intersubxectividade universal da linguaxe- socava a mensaxe. Polo tanto, non se trata só de que debamos denunciar esa posición de enunciación que constitúe o fundamento do contido universal enunciado -o suxeito masculino, rico e branco que proclama a universalidade dos dereitos humanos-; é moito máis importante sacar á luz a universalidade que cimenta e acaso debilita a reivindicación concreta de tal

9 Véxase Karl Marx: "Class Struggles in France», p. 95.

${ }^{10}$ G. K. Chesterton: Orthodoxy, San Francisco, Ignatius Press, 1955, p. 38. 
suxeito. A este respecto, como indicou Bertrand Russell, o exemplo supremo é o do solipsista que tenta convencer os demais de que en realidade non existe ninguén máis ca el. Poderíaselle aplicar este argumento á tolerancia ou á intolerancia? Talvez non totalmente, malia si existir unha trampa similar na predicación da tolerancia: a de (pre)supor que se dá por presuposta -é dicir, que o suxeito está fondamente "preocupado" polo próximo-, co cal reafirma esa presuposición.

De igual modo, os monárquicos franceses foron vítimas da astucia da razón, cegos ante os intereses -republicano-capitalistas- universais aos que servían na procura dos seus obxectivos monárquicos particulares. Eran como o valet de chambre de Hegel, que, como non ve a dimensión universal, non ten heroes. De maneira máis xeral, un capitalista cre que a súa actividade redunda no seu propio beneficio, ignorando que está a servir á expansión da reprodución do capital universal. Non se trata só de que toda universalidade estea acosada por un contido particular que a luxa: é que toda posición concreta está acosada pola súa universalidade implícita, que a vai socavando. $\mathrm{O}$ capitalismo non é meramente universal "por si», é universal "para si», xa que constitúe ese tremendo poder corrosivo real que mina todas as vidas-mundos, culturas e tradicións particulares, que os abrangue a todos, que os atrapa no seu vórtice. Non ten sentido facer a pregunta de «esta universalidade é verdadeira ou enmascara intereses particulares?». Esta universalidade é directamente real en canto que universalidade, en canto que forza negativa de mediación e destrución de todo contido particular.

Velaquí o momento da verdade que se dá na reivindicación liberalista da universalidade kulturlos: o capitalismo, cuxa ideoloxía é o liberalismo, é certamente universal, xa non está arraigado nunha cultura ou «mundo» específicos. Por iso Badiou afirmou hai pouco que a nosa época «carece de mundo»: porque a universalidade do capitalismo reside en que con «capitalismo» non se designa unha «civilización», un mundo simbólico-cultural concreto, senón unha máquina simbólico-económica verdadeiramente neutral que funciona tanto con valores asiáticos como con outros. Nese sentido, o triunfo mundial de Europa é a súa derrota, o seu autoexterminio. Foi cortado o cordón umbilical que unía o capitalismo con Europa. Neste punto quedan curtos os críticos do eurocentrismo que se esforzan por desenterrar a secreta parcialidade do capitalismo a favor de Europa: o problema do capitalismo non é este, senón que realmente é universal, unha matriz neutral de relacións sociais. 
Aplícase a mesma lóxica á loita pola emancipación: aquela cultura que trata desesperadamente de defender a súa identidade ha de reprimir a dimensión universal que permanece activa no seu propio núcleo, ou, noutras palabras, a división que existe entre o particular -a súa identidade- e o universal que a desequilibra desde dentro. Esta é a razón de que fracase o argumento de "déixanos a nosa cultura». No seo de cada cultura concreta, os individuos si que sofren, as mulleres si que protestan cando son obrigadas a sometérense á ablación de clítoris, e estas protestas contra as limitacións provincianas impostas pola propia cultura formúlanse desde o punto de vista da universalidade, polo que sobre isto non se debería amosar comprensión ningunha. A fórmula da solidariedade revolucionaria non é «toleremos as nosas diferenzas», senón que unha mellor sería a seguinte: malia as nosas diferenzas, podemos identificar o antagonismo básico ou a loita antagonista en que ambos estamos atrapados; así que compartamos a nosa intolerancia e unamos as nosas forzas na mesma loita. Noutras palabras, no combate pola emancipación non son as culturas, na súa identidade, as que xuntan as mans; son os reprimidos, os explotados e os que sofren, as "partes de ningunha parte» de todas as culturas as que se unen nunha loita común.

A Primo Levi preguntábanlle acotío se se consideraba principalmente xudeu ou humano. El adoitaba oscilar entre estas dúas opcións. A solución evidente -a de que, precisamente como xudeu, era humano; é dicir, un é humano, participa dunha humanidade universal, mediante a súa moi particular identificación étnica- non cadra nada; a única resposta consecuente non consiste en dicir que Levi era un humano que resultaba ser xudeu, senón que era humano -participaba «por si» na función universal da humanidade- precisamente porque estaba incómodo coa súa condición de xudeu ou non era quen de identificarse totalmente con ela, e só nesa medida. «Ser xudeu» constituía para el un problema, non un feito, non un refuxio ao que se puidese retirar.

\section{ACHERONTA MOVEBO}

A substancia étnica concreta, a nosa vida-mundo, que se resiste á universalidade, está formada por hábitos. E que son os hábitos? Toda orde legal -ou toda 
orde dotada de normatividade explícita- ten que basearse nunha complexa rede de regras informais que nos din como nos debemos relacionar con esas normas explícitas, como debemos aplicalas: en que medida temos de tomalas de xeito literal, como e cando se nos permite, ou mesmo se nos solicita, que as pasemos por alto, etc.; e este é o dominio do hábito. Coñecer os hábitos dunha sociedade consiste en coñecer as metarregras que indican como aplicar as normas explícitas desa sociedade: cando usalas ou non; cando violalas; cando non facer unha escolla que se nos ofrece; cando estamos en realidade obrigados a facer algo, mais temos de finxir que o facemos porque así o decidimos libremente -como no caso do potlatch. Lémbrese a cortés «oferta que se fai para que se lle diga que non»: é un "hábito» rexeitala, e quen a acepta mete o zoco vulgarmente. $\mathrm{O}$ mesmo é aplicable a un gran número de situacións políticas en que se ofrecen alternativas coa condición de que escollamos a correcta: recórdasenos solemnemente que podemos dicir que non..., mais espérase de nós que rexeitemos esa oferta e digamos que si con entusiasmo. No caso de moitas prohibicións sexuais, a situación é a contraria: un «non» explícito funciona en realidade como a orde implícita «faino, mais con discreción!».

Unha das estratexias dos réximes "totalitarios» consiste en establecer regulamentos legais -leis penais- tan severos que, se se tomasen ao pé da letra, absolutamente todo o mundo sería culpable de algo, e logo absterse de aplicalos na súa integridade. Deste xeito, o réxime pode parecer clemente -«Mirade, se quixermos poderiamos detervos e condenarvos a todos, mais non teñades medo, que somos indulxentes...»- e, así mesmo, exercer a permanente ameaza de aplicarlles un correctivo aos seus súbditos - «Non xoguedes moito con nós, lembrade que en calquera momento podemos...». $\mathrm{Na}$ antiga Iugoslavia existía o infame artigo 133 do Código Penal, que sempre se podía invocar para axuizar escritores e xornalistas: de acordo con el, era delituoso calquera texto que presentase con falsidade os logros da revolución socialista ou que puidese crear tensión e descontento entre o público polo seu modo de abordar temas políticos, sociais ou doutra índole... Esta última categoría, como resulta obvio, non só é infinitamente plástica, senón que tamén se refire, moi convenientemente, a un mesmo: o propio feito de seres acusado polos poderosos non equivale a que "creases tensión e descontento entre o público»? Naqueles anos, acórdome de que lle preguntei a un político esloveno como xustificaba este artigo, ao cal el 
simplemente sorriu e, chiscándome o ollo, respondeu: «Ben, é que temos que contar con algunha ferramenta para disciplinarmos a vontade a aqueles que nos amolan...». Esta superposición dunha potencial culpabilización total -calquera cousa que esteas a facer pode, abofé, ser un delito- e a clemencia -o feito de que se che permita vivir a vida en paz non é proba nin consecuencia de que sexas inocente, senón de que os poderosos son clementes e benevolentes e "comprenden as realidades da vida»- é máis unha proba de que os réximes «totalitarios»son, por definición, réximes de clemencia, de tolerancia dos incumprimentos legais, posto que o modo en que enmarcan a vida social, contravindo a lei -subornando, enganando...-, é unha condición necesaria para a supervivencia.

O problema que xurdiu durante os caóticos anos postsoviéticos do mandato de Yeltsin en Rusia pódense situar a este nivel; malia seren coñecidas as normas legais -que eran, en boa medida, as mesmas que coa Unión Soviética-, a fonte de desintegración era o complexo tecido de normas implícitas e non escritas que apuntalaban todo o edificio social. Por exemplo, se na Unión Soviética un quería recibir un mellor tratamento hospitalario, facerse cun piso novo, se tiña unha queixa das autoridades, se o citaban no xulgado, se quería que o fillo entrase nun destacado centro educativo, se o director dunha fábrica precisaba materias primas que os contratistas estatais non entregaban en tempo, etc., todo o mundo sabía o que realmente había que facer, a quen dirixirse, a quen subornar, o que se podía facer e o que non. Logo da caída do poder soviético, un dos aspectos máis frustrantes da existencia diaria da xente corrente radicaba en que estas regras non escritas, en boa medida, esvaeceron: un simplemente non sabía que facer, como reaccionar, que relación manter cos regulamentos legais explícitos, que se podía pasar por alto, onde valían os subornos, etc. Unha das funcións da delincuencia organizada consistía en ofrecer unha especie de legalidade Ersatz: se un posuía un pequeno negocio e un cliente lle debía cartos, acudíase ao protector mafioso e este encargábase do problema, dado que o sistema legal do Estado era ineficaz. A estabilización nada co «reinado» de Putin, basicamente, equivale a un restablecemento da transparencia destas normas non escritas: agora, de novo, polo xeral, a xente sabe como actuar e reaccionar na complexa arañeira de interaccións sociais.

Tamén por este motivo, o nivel máis elemental de intercambio simbólico vén representado polos chamados "xestos baleiros», ofertas que se fan para seren 
rexeitadas ou que están destinadas a iso mesmo. Foi Brecht quen lle deu unha conmovedora expresión a esta característica nas súas obras de teatro de aprendizaxe, e de xeito exemplar en Jasager, na cal se lle pide ao rapaz que concorde libremente co que, en calquera caso, vai ser o seu destino -ser lanzado ao val-; como lle explica o mestre, é costume preguntarlle á vítima se está de acordo coa súa sorte, mais tamén é costume que a vítima diga que si. Pertencer a unha sociedade comporta un punto paradoxal no que a cada un de nós se nos ordena abrazar libremente, por elección propia, o que de todos os xeitos se nos impón -todos debemos amar o noso país e os nosos pais. Este paradoxo de desexar, decidindo libremente, o que en calquera caso é necesario, de finxir, mantendo as aparencias, que hai liberdade de elección aínda que realmente non a haxa, vai en estrita codependencia coa noción de xesto simbólico baleiro -xesto ofertadestinado a ser rexeitado.

E non son semellantes algunhas das nosas convencións cotiás? No Xapón dos nosos días, os traballadores teñen dereito a corenta días de vacacións ao ano; porén espérase deles que non exerzan este dereito en toda a súa extensión -a regra tácita é non usar máis da metade dos días. Así, en A Prayer for Owen Meany (Oración por Owen Meany), logo de que o pequeno Owen mate accidentalmente a nai de John, o seu mellor amigo e o narrador, séntese, xaora, sumamente afectado; así que, para dar proba do seu pesar, lle regala a John discretamente a colección completa de fotos en cor de estrelas do béisbol, a súa posesión máis prezada. Mais Dan, o delicado padrasto de John, dille que o axeitado é devolver o galano.

Imaxinemos agora unha situación máis realista: cando, logo de competir feramente por un ascenso co meu amigo máis íntimo, gaño eu, o axeitado é ofrecerme a botarme atrás para que el consiga o ascenso, e o axeitado é que el rexeite o meu ofrecemento; así talvez se poida salvar a nosa amizade. O que temos aquí é un intercambio simbólico no seu sentido máis puro: un xesto feito para ser rexeitado. A maxia do intercambio simbólico radica en que, malia que finalmente estamos onde estabamos ao principio, ambas as partes obteñen un claro beneficio no seu pacto de solidariedade. Unha lóxica semellante funciona no proceso de pedir perdón: se firo os sentimentos de alguén cun comentario groseiro, o que debo facer é ofrecerlle unha desculpa sincera, e o que debe facer el é dicir algo así como: «Grazas, moi amable, mais non me ofendiches, xa sabía que 
non o dicías en serio, así que non fai falla que te desculpes!». A cuestión é, por suposto, que, malia resultar ao cabo que non é preciso desculparse, un ten que pasar por todo o proceso de pedir perdón: «non fai falla que te desculpes» só se pode dicir logo de que eu efectivamente pida desculpas, de xeito que, aínda que no sentido formal "non pasa nada» e se proclama que a petición de desculpas é innecesaria, algo se gaña ao final do proceso, talvez mesmo se salve a amizade.

O problema, sen dúbida, é o seguinte: que acontece se a persoa a quen se lle fai ese ofrecemento destinado a ser rexeitado efectivamente o acepta? Que ocorre se, despois de ser vencido nesa competición, acepto o ofrecemento do meu amigo de ser ascendido no canto del? Que sucedería se Rusia realmente comezase a actuar como gran potencia? Acontece que unha situación así é, falando claramente, catastrófica: causa a desintegración da aparencia de liberdade de que está revestida a orde social, o cal equivale á desintegración da propia substancia social, á disolución do vínculo social. Neste preciso sentido, as figuras igualitario-revolucionarias, desde Robespierre a John Brown, son, cando menos en potencia, figuras carentes de hábitos: néganse a ter en consideración os hábitos que permiten o funcionamento dunha regra universal. Así, se todos os homes son iguais, todos os homes son iguais e deben ser tratados efectivamente como tales; se os negros tamén son humanos, deberían ser tratados inmediatamente como tales.

A escala menos radical, nos primeiros anos do decenio de 1980, na antiga Iugoslavia houbo un semanario estudantil semidisidente que quixo protestar contra as falsas eleccións «libres» e, consciente das limitacións da consigna «dille a verdade ao poder»-«O problema desta consigna é que pasa por alto o feito de que o poder non vai escoitar e a xente xa sabe a verdade, como deixa claro nas súas brincadeiras» ${ }^{11}$, , no canto de denunciar directamente a ausencia de liberdade nas eleccións, decidiu tratalas como se realmente fosen libres, como se o resultado realmente non estivese xa decidido. Así, na véspera das eleccións, imprimiron unha edición extra do xornal que levaba un gran titular: «Resultados das últimas eleccións: ¡parece que os comunistas van seguir no poder!». Con esta simple intervención rompeuse o "hábito» non escrito - «todos sabemos» que as eleccións non son libres, simplemente é que non falamos diso en público...-; ao tratar as eleccións como se fosen libres, lembróuselle publicamente á xente a súa falta de liberdade.

${ }^{11}$ Moustapha Safouan: Why Are the Arabs Not Free: the Politics of Writing (inédito). 
Na segunda temporada da serie de televisión Quita e pon, Sean recibe a nova de que o verdadeiro pai de Matt, o seu fillo adolescente, é Christian, o seu compañeiro. A súa reacción inicial é un arrebato de cólera; posteriormente, logo dunha operación para separar dous xemelgos siameses que non conclúe con éxito, volve aceptar a Chris como compañeiro, dando un gran discurso preto da mesa de operacións: «Non te vou perdoar nunca o que fixeches, pero Matt é valioso de máis, o mellor resultado da nosa colaboración, así que non deberiamos perder isto...». Esta obvia mensaxe, demasiado obvia - unha solución moito máis elegante sería que Sean simplemente dixese: «Non te vou perdoar nunca o que fixeches», onde a posición subxectiva do enunciado xa é a de aceptaciónamosa como fala un con outra persoa á que xa ten decidido volver aceptar. Daquela, o problema é que Sean di demais. Por que segue? Velaquí a cuestión máis interesante. É que o público estadounidense é estúpido? Non tal. Logo por que? E se, dado que un mero sinal de que novamente hai verdadeira aceptación sería demasiado, intenso de máis, eses tópicos explícitos están aí para atenualo? Como Quita e pon é unha serie estadounidense, talvez se poida explicar este exceso pola diferenza que existe entre Europa e os Estados Unidos. En Europa, o baixo dun edificio cóntase como cero, de xeito que o piso que hai enriba del é o "primeiro piso", mentres que nos Estados Unidos o "primeiro piso" está ao nivel da rúa. En resumo, os estadounidenses empezan a contar en un, mentres que os europeos saben que o un xa é un substituto de cero; ou, para dicilo con xiros máis históricos: os europeos son conscientes de que, antes de comezar a contar, ten que haber unha tradición «de base», unha base que xa vén sempre dada e que, como tal, non se pode contar, mentres que nos Estados Unidos, terra que carece de tradición histórica premoderna propiamente dita, falta esa «base». Alí as cousas comezan directamente coa autolexislación da liberdade, bórrase o pasado, trasponse a Europa ${ }^{12}$. Por iso, hai que complementar esta falla de base dicindo máis do necesario: Sean non se pode apoiar nunha base simbó-

12 Talvez esta característica explique outro estraño fenómeno: en «case» todos os hoteis estadounidenses situados en edificios de máis de doce pisos, non hai piso décimo terceiro, para evitar a mala sorte, por suposto; é dicir, sáltase directamente do piso doce ao catorce. Para un europeo este procedemento non ten sentido: a quen intentamos enganar? Como se Deus non soubese que o que designamos como piso catorce é en realidade o trece! Os estadounidenses xogan a isto precisamente porque o seu Deus non é máis que unha prolongación do seu ego individual e non se percibe en canto verdadeiro fundamento da existencia. 
lica que garantiría que Christian captase a mensaxe sen que esta se pronunciase explicitamente.

Os hábitos, xa que logo, son a verdadeira substancia de que está feita a nosa identidade: con eles enunciamos e, en consecuencia, definimos o que realmente somos en canto que seres sociais, o cal acotío contrasta con como percibimos o que somos. Coa súa transparencia mesma, os hábitos constitúen o medio polo que se manifesta a violencia social. Xa en 1937, George Orwell ${ }^{13}$ despregou a ambigüidade da actitude predominante que amosaba a esquerda con respecto á diferenza de clases:

Todos estamos contra as distincións de clase, mais moi poucos queren en serio abolilas. Neste punto atopamos a importante cuestión de que toda opinión revolucionaria tira parte da súa forza da secreta convicción de que non se pode mudar ren [...]. Sempre que non se trate de máis nada que de mellorar a sorte do traballador, todas as persoas decentes están de acordo [...]. Mais, infelizmente, non se chega a ningures simplemente con desexar que rematen as distincións de clase; ou, para dicilo con máis exactitude, si é preciso desexar que rematen, pero ese desexo carece de eficacia a menos que se entenda o que comporta. Ao que hai que enfrontarse é a que abolir as distincións de clase significa abolir unha parte dun mesmo. Aquí estou eu, membro típico da clase media; resúltame doado dicir que quero librarme das distincións de clase, mais case todo o que penso e fago é consecuencia delas [...]. Teño de alterar o meu ser dun xeito tan completo que, ao cabo, mal se me recoñecerá como a mesma persoa.

O que apunta Orwell é que os radicais invocan a necesidade da mudanza revolucionaria como se fose unha especie de prenda supersticiosa destinada a acadar o contrario, é dicir, evitar que esa mudanza se produza realmente; así, a un estudoso de esquerdas de hoxe que critique o imperialismo cultural capitalista, en realidade, horrorízalle a idea de que o seu campo de estudo poida virse abaixo. Porén, esta estratexia ten un límite. As apreciacións de Orwell só son válidas no caso de determinada clase de «burgueses» de esquerdas, porque hai xente de esquerdas que si ten a coraxe que lle dan as súas conviccións, que non quere só unha «revolución sen revolución», como o expresou Robespierre -os xacobinos e

\footnotetext{
13 Véxase George Orwell: The Road to Wigan Pier, (1937).
} 
os bolxeviques, entre outros... O punto de partida destes revolucionarios xenuínos pode ser a mesma posición dos «burgueses» de esquerda; o que acontece é que, en plena pose pseudorradical para a galería, se enredan no seu propio xogo e están dispostos a cuestionaren a súa postura subxectiva. Resulta difícil imaxinar un exemplo político máis mordaz que teña o peso da distinción lacaniana entre o «suxeito do enunciado» e o "suxeito da enunciación»: primeiro, en sentido negativo, empézase por querer "cambiar o mundo» sen pór en perigo a postura subxectiva desde a que se está disposto a facer realidade ese cambio; logo, coa «negación da negación», o suxeito que promulga a mudanza está disposto a pagar o prezo subxectivo por ela, a cambiarse a si mesmo ou, para citar a bela fórmula de Gandhi, a ser el mesmo a mudanza que quere ver no mundo. Por iso Orwell ten claro que, no noso decorrer cotián ideolóxico, mantemos predominantemente unha actitude de distancia irónica con respecto ás nosas verdadeiras crenzas:

$\mathrm{O}$ «intelectual» medio ten unhas opinións esquerdistas que son basicamente espurias; por pura imitación apupa cousas en que, de feito, cre. Por poñer un exemplo entre moitos, tomemos o código de honra da escola pública, coa súa «mentalidade de equipo» e o «Non lle batas a un home cando está caído», e todas as demais parvadas que tan familiares nos resultan. Quen non se riu delas algunha vez? Que persoa que se chame a si mesma «intelectual» non ousaría rirse delas? Mais a cousa cambia un pouco cando nos topamos con alguén que se ri desde fóra, igual que pasamos a vida meténdonos con Inglaterra pero nos enfurecemos cando oímos un estranxeiro que di exactamente iso [...]. Non é ata coñecermos unha persoa dunha cultura distinta da nosa cando comezamos a nos decatar de cales son en realidade as nosas propias crenzas.

Esta verdadeira identidade ideolóxica non ten nada de «interior»: as miñas crenzas máis íntimas están todas «aí fóra», encarnadas en prácticas que chegan ata a materialidade inmediata do meu corpo.

As miñas nocións -do ben e do mal, do agradable e desagradable, do chistoso e do serio, da fealdade e da beleza- son esencialmente nocións de clase media; os meus gustos en literatura, gastronomía e vestiario, o meu sentido da honra, os meus modais na mesa, os xiros que emprego ao falar, o meu acento, mesmo os movementos característicos do meu corpo $[\ldots]$ 
Definitivamente habería que engadirlle a esta serie o olfacto: talvez a diferenza fundamental que separa a clase baixa popular e a clase media se refira ao xeito de relacionárense cos olores. Para a clase media, as clases baixas cheiran, os seus membros non se lavan con regularidade; ou, para citarmos a proverbial resposta dun parisiense de clase media á pregunta de por que no metro prefería ir nos vagóns de primeira: «Non tería problema en ir cos traballadores en segunda, pero é que cheiran!». Isto lévanos a unha das posibles definicións do que quere dicir semellante nos nosos días: o noso semellante é aquel que, por definición, cheira. Por iso hoxe son fundamentais os desodorizantes e xabóns, porque fan que os veciños sexan cando menos minimamente tolerables: estou disposto a amar o meu semellante... sempre que non cheire moi mal. Segundo un informe recente, os científicos dun laboratorio de Venezuela engadíronlle outro elemento a esta serie: mediante manipulacións xenéticas, lograron cultivar fabas que, cando se comen, non producen eses gases fedorentos que tan embarazosos resultan en ambientes sociais! E así, despois do café descafeinado, os pasteis sen graxa, a cola light e a cervexa sen alcol, agora temos fabas que non producen gases ${ }^{14}$. Lacan complementou a lista de Freud de obxectos parciais - peitos, feces, pene-con outros dous: a voz e mais a mirada. Talvez habería que sumarlle outro obxecto a esta serie: o olfacto.

Deste xeito chegamos ao «corazón da escuridade» dos hábitos. Lémbrense os numerosos casos de pedofilia que lle afectan á Igrexa católica: cando os seus representantes insisten en que estes casos, por moi deplorables que sexan, constitúen un problema interno da Igrexa e se mostran remisos a colaborar coa policía nas súas investigacións, en certo modo teñen razón. A pedofilia dos sacerdotes católicos non é algo que lles concirna meramente a aquelas persoas que, por motivos accidentais da súa historia privada, sen relación ningunha coa Igrexa como institución, resulta que escolleron a profesión do sacerdocio; trátase dun fenómeno que lle concirne á Igrexa católica como tal, que se inscribe no propio funcionamento desta en canto que institución socio-simbólica. Non lle afecta ao inconsciente "privado» dos individuos, senón ao «inconsciente» da institución mesma: non é unha cousa que ocorre porque esta institución, para sobrevivir,

\footnotetext{
${ }^{14}$ Aínda que, mesmo neste punto, o benévolo Estado do benestar se esforza por equilibrar a molestia que supón o veciño fedorento e os aspectos sanitarios: hai un par de anos, o Ministerio de Saúde holandés aconselloulles aos cidadáns botaren fóra os gases polo menos quince veces ao día, a fin de evitaren que o corpo se vise sometido a tensións e presións para a saúde.
} 
teña que axeitarse ás realidades patolóxicas da vida libidinosa, senón algo que a propia institución necesita para reproducirse. Ben podemos imaxinar un sacerdote "hetero», non pedófilo, que, logo de anos de servizo, se implica na pedofilia porque a mesma lóxica da institución o seduce nese sentido. Ese inconsciente institucional designa a cara escura, obscena e negada que, precisamente por ser negada, constitúe o piar en que se apoia esa institución pública. No exército, esa cara escura comprende os obscenos rituais sexualizados de eliminación dun superior e demais, que apuntalan a solidariedade do grupo. Noutras palabras, non se trata simplemente de que, por razóns de conformismo, a Igrexa trate de silenciar os embarazosos escándalos de pedofilia; é que, ao defenderse, a Igrexa defende o seu obsceno segredo máis íntimo. O que isto significa é que identificarse con esta cara secreta é un compoñente clave da propia identidade dun sacerdote cristián: se un deles denuncia en serio, non só con retórica, estes escándalos, ao facer tal exclúese da comunidade eclesiástica, xa non é «un de nós», exactamente igual que se, no decenio de 1920, un cidadán dunha vila do Sur dos Estados Unidos denunciaba o Ku Klux Klan á policía, excluíase a si mesmo desa comunidade; é dicir, traizoaba a solidariedade comunitaria fundamental. En consecuencia, a resposta que habería que dar ante a reticencia da Igrexa non debería ser simplemente a de que estamos a falar de casos de delitos e que, se a Igrexa non participa plenamente na investigación, é cómplice dese feito; o que é máis, a Igrexa como tal, como institución, debería ser investigada por como crea sistematicamente as condicións para que eses delitos se produzan.

É esta escandalosa cara oculta dos hábitos o que resulta realmente difícil de cambiar; por iso o lema de toda revolución radical é o mesmo que a cita de Virxilio que Freud escolleu como epígrafe de $A$ interpretación dos soños: Acheronta movebo, atrévete a mover o que está soterrado! Así, Humoresca, probablemente a obra mestra de Robert Schumann para piano, debe interpretarse no contexto da gradual ausencia de voz nas súas cancións: non é unha mera peza para piano, senón unha canción sen frase vocal, na que a frase vocal se ve reducida ao silencio, de xeito que o único que en realidade oímos é o acompañamento de piano. Así se debería interpretar a famosa "voz interior / innere Stimme» engadida por Schumann, na partitura escrita, como terceira frase entre as dúas do piano, máis aguda e máis grave respectivamente: como frase melódica vocal que segue a ser unha «voz interior» non vocalizada, unha serie de variacións sen tema, un acom- 
pañamento sen frase melódica principal, que existe unicamente como Augenmusik, música só para os ollos, en forma de notas escritas. Esta melodía ausente hase reconstruír tendo en conta que o primeiro e o terceiro niveis, as frases de piano para a man dereita e a esquerda, non están directamente relacionados; é dicir, a súa relación non é de reflexo inmediato, senón que, para explicar a súa mutua conexión, un se ve obrigado a (re)construír un terceiro nivel, «virtual» e intermedio, unha frase melódica, que, por razóns estruturais, non se pode interpretar. A súa condición é a dun real-imposible que só pode existir en forma de escritura; noutras palabras, a súa presenza física aniquilaría as dúas frases melódicas que efectivamente oímos na realidade, como non «están a bater nun neno», no cal a escena fantástica intermedia nunca era unha escena consciente e tiña que reconstruírse en canto que elo perdido entre a primeira escena e a última.

Schumann leva este procedemento da melodía ausente ata unha autorreferencia aparentemente absurda cando, nunha parte posterior do mesmo fragmento da Humoresca, repite as mesmas dúas frases melódicas que efectivamente se interpretan, mais desta vez a partitura non contén unha terceira frase melódica ausente, unha voz interior; o que está ausente aquí é a melodía ausente, é dicir, a ausencia mesma. Como temos que interpretar estas notas cando, no plano do que en efecto hai que tocar, repiten exactamente as notas anteriores? As notas que si se tocan están privadas unicamente do que non está aí, da súa falla constitutiva, ou, para referirmonos á Biblia, fáltalles mesmo o que nunca tiveron. Por iso, un pianista de verdade ten que dispor do savoir faire necesario para interpretar as notas existentes, as notas positivas, de tal modo que un sexa quen de discernir o eco das notas virtuais «silandeiras» e non tocadas que as acompañan, ou a ausencia delas.

E logo non é así como funciona a ideoloxía? O texto, ou a práctica, ideolóxico explícito está sostido pola serie "non interpretada» de escandalosos complementos do superego. No Socialismo que Existe de Verdade, a ideoloxía explícita da democracia socialista estaba apuntalada por un conxunto de inmorais mandatos e prohibicións implícitos, tácitos, que lle aprendían ao suxeito a non tomar en serio determinadas normas explícitas e a aplicar unha serie de prohibicións non recoñecidas publicamente. Unha das estratexias da disidencia nos últimos anos do socialismo foi precisamente a de tomar a ideoloxía imperante moito máis en serio e dun modo moito máis literal do que esta se tomaba a si mesma, 
e a disidencia fíxoo pasando por alto a sombra virtual e non escrita desa ideoloxía: «Queres que practiquemos a democracia socialista? Vale, pois alá imos!». E, cando nos apparatchiks do Partido se captaban indicios desesperados de que non era así como funcionaban as cousas, simplemente non había que prestarlles atención... Isto é o que significa acheronta movebo en canto que práctica da crítica da ideoloxía: non alterar directamente o texto explícito da lei, senón, polo contrario, intervir no seu escandaloso suplemento virtual. Lémbrese a relación que existe cos homosexuais nunha comunidade de soldados, que funciona en dous niveis claramente diferenciados: a homosexualidade explícita é branco de brutais ataques, déixase á marxe a aqueles que se identifican como homosexuais, bátese neles todas as noites, etc.; porén, esta explícita aversión cara aos homosexuais vese acompañada por un conxunto excesivo de redes implícitas de indirectas á homosexualidade, brincadeiras privadas, prácticas obscenas, etc. Daquela, ao intervir dun xeito verdadeiramente radical na aversión militar polos homosexuais non habería que centrarse sobre todo na represión explícita da homosexualidade; polo contrario, habería que "mover o que está soterrado», alterar as prácticas homosexuais implícitas que lle serven de apoio á aversión explícita.

É esta escandalosa parte clandestina a que nos permite abordar doutra maneira o fenómeno de Abu Ghraib. Aínda se lembra alguén do desgraciado Muhammad Saeed al-Sahhaf, o ministro de Información de Saddam que, nas súas roldas de prensa diarias, negaba con heroísmo mesmo os feitos máis evidentes e se cinguía á liña iraquí? Que, cando os tanques estadounidenses estaban só a uns centos de metros do seu despacho, seguía a afirmar que as imaxes dos tanques nas rúas de Bagdad que amosaba a televisión estadounidense non eran máis que efectos especiais de Hollywood? Porén, dunha vez si deu cunha estraña verdade: cando, ao se enfrontar ás afirmacións de que o exército estadounidense xa tiña o control dalgunhas zonas de Bagdad, retrucou con brusquidade: «Non teñen o control de nada, se nin sequera se controlan a si mesmos!». Cando saíu á luz a escandalosa nova das cousas tan peculiares que pasaban no cárcere de Abu Ghraib, en Bagdad, albiscamos esta mesma dimensión que os estadounidenses non controlan no seu interior.

Como reacción ás fotografías en que se vían prisioneiros iraquís torturados e humillados polos soldados estadounidenses, e que se fixeron públicas a finais de abril de 2004, George Bush, como era de esperar, subliñou que os actos dos sol- 
dados constituían delitos illados que non reflectían aquilo que os Estados Unidos defenden e polo que loitan, os valores da democracia, a liberdade e a dignidade persoal. E, en efecto, o feito mesmo de que o caso se convertese nun escándalo público que puxo o Goberno estadounidense á defensiva foi por si mesmo un sinal positivo; nun verdadeiro réxime "totalitario», simplemente se botaría terra sobre o caso. Do mesmo xeito, non esquezamos que o feito mesmo de que as forzas estadounidenses non atopasen armas de destrución masiva é un sinal positivo: unha verdadeira potencia «totalitaria» faría o que adoitan facer os polis, que é chantar alí droga e logo «descubrir» as probas do delito.

Con todo, existen algúns trazos desacougantes que complican ese sinxelo panorama. A principal característica que salta á vista é o contraste existente entre o modo "habitual» de torturar os prisioneiros no anterior réxime de Saddam e as torturas aplicadas polo exército estadounidense. Baixo o réxime anterior, púnase o acento en inflixir directamente unha dor brutal, mentres que os soldados dos Estados Unidos se centraban na humillación psicolóxica. Usar unha cámara para deixar constancia da humillación, sacando os autores na imaxe, cun sorriso estúpido na cara e situados preto dos corpos nus e retortos dos prisioneiros, é parte integral do proceso, en marcado contraste co segredo que rodeaba as torturas de Saddam. Cando vin a famosa foto dun prisioneiro espido que tiña a cabeza tapada cunha carapucha negra e cables eléctricos aplicados ás extremidades, de pé enriba dunha cadeira nunha ridícula pose teatral, a miña reacción inicial foi a de pensar que se trataba dunha imaxe dalgún dos últimos espectáculos artísticos do Lower Manhattan. A postura e a vestimenta dos prisioneiros suxiren unha representación teatral, unha sorte de tableau vivant, que non pode senón traernos á mente todo o abano de artes interpretativas estadounidenses e o "teatro da crueldade», as fotografías de Mapplethorpe, as estrañas escenas das películas de David Lynch...

E é este trazo o que nos leva ao celme da cuestión: para calquera persoa que estivese familiarizada coa realidade do modo de vida estadounidense, as fotos evocaban inmediatamente a espantosa cara oculta da cultura popular do país; por exemplo, os rituais iniciáticos de tortura e humillación polos que hai que pasar para ser aceptado nunha comunidade pechada. E logo na prensa estadounidense non vemos fotografías semellantes a intervalos regulares, cando sae á luz un escándalo acontecido nunha unidade do exército ou nun campus universita- 
rio, onde o ritual iniciático se lles foi da man e algún soldado ou estudante foi ferido nunha medida superior á considerada tolerable, obrigado a adoptar unha posición humillante, a realizar xestos degradantes, como penetrar na súa propia abertura anal cunha botella de cervexa diante dos compañeiros, a sufrir que o piquen con agullas, etc.? E, por certo, dado que o propio Bush é membro da Skull and Bones, a sociedade secreta máis exclusiva do campus de Yale, sería interesante saber a que rituais tivo que someterse para ser aceptado.

Existe, por suposto, unha diferenza obvia, que radica en que, no caso deses rituais iniciáticos -como dá fe o seu propio nome-, un se somete a eles porque así o elixiu libremente, sendo plenamente consciente do que debe esperar deles e tendo en mente o claro obxectivo da recompensa que agarda por el, ser aceptado no círculo interno e, por último, mais non por iso menos importante, que lle permitan realizarlles os mesmos rituais aos membros novos; mentres que en Abu Ghraib, os rituais non eran o prezo que tiñan que pagar os prisioneiros para seren aceptados como «un de nós», senón, polo contrario, a marca mesma da súa exclusión. Porén, non atopamos na «liberdade de elección» daqueles que se someten aos humillantes rituais de iniciación un caso exemplar de falsa liberdade de elección, nun sentido semellante ao da liberdade que ten o traballador para vender a súa forza laboral? O que é aínda peor, chegados a este punto habería que lembrar un dos rituais máis noxentos da violencia contra os negros do vello sur estadounidense: un negro é acantoado por matóns brancos que despois o obrigan a realizar un xesto agresivo - «Cúspeme na cara, neno!»; «Di que son un merdeiro!»...-, o cal ten como obxecto xustificar a malleira ou o linchamento que vén a seguir. É máis, tamén está o exemplo definitivo de cinismo da mensaxe que se transmite ao aplicarlles aos prisioneiros árabes o ritual iniciático propiamente estadounidense: queres ser un de nós? Vale, pois proba un pouco do núcleo mesmo do noso modo de vida.

Lémbrese a película de Rob Reiner Algúns homes bos, drama sobre un tribunal militar no que se xulga a dous marines estadounidenses acusados de asasinar outro dos soldados; o fiscal militar afirma que ese acto constituíu un asasinato deliberado, mentres que a defensa -formada por Tom Cruise e Demi Moore, como ían fracasar?- consegue demostrar que os acusados seguiran o chamado "Código Vermello», a regra non escrita dunha comunidade militar, que autoriza as malleiras nocturnas clandestinas daquel soldado que viole as normas éticas dos 
Marines. Ese código aproba un acto de transgresión, é «ilegal», mais, así mesmo, reafirma a cohesión do grupo. Ten que ficar baixo o amparo da noite, non recoñecido, inefable; en público, todos finxen non saber nada del, ou mesmo negan efectivamente que exista, e o punto culminante do filme é, como era de esperar, a explosión de rabia de Jack Nicholson, o oficial que ordenara a malleira nocturna: ese estoupar en público constitúe, por suposto, o momento da súa caída.

Mesmo atentando contra as regras comunitarias explícitas, este código representa o «espírito de comunidade» en toda a súa pureza ao exercer a maior presión para que os individuos poñan en práctica a identificación co grupo. A diferenza do que acontece coa lei explícita escrita, un código do superego tan escandaloso é esencialmente verbal. Mentres que a lei explícita se apoia no pai morto en canto autoridade simbólica, o "Nome do Pai», o código non escrito susténtase no suplemento espectral do «Nome do Pai»: a espantosa pantasma do "pai primordial» freudiano ${ }^{15}$. Aí reside a lección que se tira do Apocalypse Now de Coppola: na figura de Kurtz, ese "pai primordial» -o inmoral pai-gozo non subordinado a lei simbólica ningunha, o amo total que ousa enfrontarse cara a cara co real do gozo aterrador- preséntase non como resto dun pasado de barbarie, senón como o resultado necesario do propio poder do Occidente moderno. Kurtz era un soldado perfecto; como tal, ao sobreidentificarse co sistema do poder militar, converteuse no exceso que o sistema ten que eliminar. O horizonte último de Apocalypse Now é esta apreciación de como o poder xera o seu propio exceso, que ha de aniquilar mediante unha operación que ten que imitar aquilo contra o que loita, así, a misión de matar a Kurtz que se lle asigna a Willard non existe para efectos oficiais, "nunca aconteceu», como sinala o xeneral que informa a Willard. Dese xeito penetramos no dominio das operacións secretas, do que fai o poder sen nunca o admitir. Isto é o que non captou Christopher Hitchens cando escribiu:

Unha de dúas, por necesidade: ou ben estes matóns actuaban baixo a autoridade doutra persoa, caso no cal existe unha camada de individuos situados nun nivel entre medio e alto que cren que non teñen a obriga de acataren as leis, códigos e regulamentos; ou ben actuaban baixo a súa propia autoridade e, neste caso, sobre o terreo son o equivalente

\footnotetext{
${ }^{15}$ Para consultar un estudo máis detallado sobre este tema, véxase o capítulo 3 de Slavoj Žižek: The Metastases of Enjoyment, Londres, Verso Books, 1995.
} 
de amotinados, desertores ou traidores. Por iso un pregunta a si mesmo con nostalxia se os procedementos da xustiza militar non conteñen disposición ningunha segundo a cal hai que levalos fóra e pegarlles un tiro ${ }^{16}$.

O problema é que as torturas de Abu Ghraib non foron ningunha destas dúas posibilidades: malia non poderen ser reducidas a meros actos de maldade dalgúns soldados illados, tampouco se ordenou directamente, por suposto, que se levasen a cabo, senón que derivaron a súa lexitimación dunha particular versión das inmorais regras do "Código Vermello". Afirmar que estes, «sobre o terreo», foron actos de "amotinados, desertores ou traidores» é tan disparatado como dicir que os linchamentos do $\mathrm{Ku}$ Klux Klan foron accións efectuadas polos traidores da civilización católica occidental e non un arrebato da espantosa cara oculta desta, ou que os abusos a nenos cometidos por sacerdotes católicos son actos de traidores do catolicismo.

Abu Ghraib non constituíu simplemente un caso de arrogancia estadounidense cun pobo do Terceiro Mundo: ao seren sometidos a esas humillantes torturas, os prisioneiros iraquís foron, de feito, iniciados á cultura estadounidense, probaron un pouco da inmoralidade da súa cara oculta, que constitúe o suplemento necesario dos valores públicos de dignidade persoal, democracia e liberdade. Por iso Bush estaba enganado: o que captamos cando vemos na pantalla ou na primeira páxina do periódico as fotografías dos humillados prisioneiros iraquís é precisamente unha apreciación directa dos "valores estadounidenses», do núcleo mesmo do gozo inmoral que constitúe o piar do modo de vida do país. Deste xeito, as fotografías puxeron na perspectiva adecuada a famosa tese de Samuel Huntington sobre o actual «choque de civilizacións»: o que se produce entre a civilización árabe e a estadounidense non é un choque entre a barbarie e o respecto pola dignidade humana, senón entre a brutal tortura anónima e a tortura como espectáculo nos medios de comunicación, no cal o corpo das vítimas representa o pano de fondo sobre o que se sitúa a face «de inocente estadounidense» dos propios torturadores, a sorriren estupidamente. Así mesmo, aquí temos unha proba de que, para parafrasear a Walter Benjamin, todo choque de civilizacións é o choque das barbaries subxacentes.

${ }^{16}$ C. Hitchens: «Prison Mutiny», dispoñible en liña (publicado o 4 de maio de 2004). 